\title{
Slovene Operetta at the Crossroads: Radovan Gobec's Planinska roža
}

\author{
Niall 0'Loughlin \\ Univerza v Loughboroughu \\ Loughborough University
}

\section{The Background - Opera and Operetta}

From its very early development opera was considered a serious attempt to recreate the drama of classical Greece. This included many mythical plots involved with the Trojan War and its consequences. For the ancient Greeks this was central to their theatrical experience. The innovations of the Florentine Camerata of the 17th century had aimed to recreate these dramas with the then current musical forms, especially recitative, arioso and aria. The first major opera, Orfeo by Claudio Monteverdi, instilled the mythical story of Orpheus and Euridice with a dramatic element which was generally lacking in the earlier operas, making the opera operate on a serious emotional level. ${ }^{1}$ As opera developed as a form, a number of different styles appeared, with numerous distinct variations in its character appearing, often indicated by different labels, e. g. opera seria and opéra comique. ${ }^{2}$ By the later 18th century opera seria was well established, for example, in Mozart's operas Idomeneo and La clemenza di Tito, ${ }^{3}$ but even then it was considered rather old-fashioned. Reaction against serious opera was well established

$1 \quad J o h n$ Whenham, Claudio Monteverdi Orfeo (Cambridge: Cambridge University Press, 1986), 42-77, discusses the dramatic action and its music in some detail.

2 The notorious Querelle des bouffons which took place in Paris in the years 1752 to 1754 ended in a 'triumph' for Italian music over French. More significantly this was 'the triumph of comic opera over serious opera', as Edward J. Dent wrote in Mozart's Operas: A Critical Study (London: Oxford University Press, 1947), 9. 
in the classical period, with numerous lighter works with genres such as opera buffa, but including the two greatest operas of the Classical period, Mozart's Le nozze di Figaro and Don Giovanni, both of which embrace the lighter and serious styles in a brilliant synthesis. ${ }^{4}$ Mozart was also involved in the German Singspiel, including lighter operas, with dance routines and spoken dialogue rather than formal recitative, notably Die Entführung aus dem Serail and Die Zauberflöte.5 The composer Chistoph Willibald Gluck (1714-1787) made a more conscious attempt to reform opera by reducing the length of baroque operas, with the omission of da capo sections and other features. The operas of Gluck, consequently, were well received in Paris, notably Orfée.

In France in the 19th century, this reaction to new and serious opera continued the conflict with what we now see as an populist attack on the whole idea of serious opera. The operas of Berlioz suffered some terrible indignities at the hands of the troublemakers of the Parisian press and public. For example, in 1838 Berlioz's adventurous Benvenuto Cellini was subjected to a barrage of abuse and ill-informed criticism, as well as by many of his performers who were unable to understand the composer's style. ${ }^{6}$ Berlioz's Les Troyens met with great resistance because it was a long opera based on the classical story of Troy and Rome, ${ }^{7}$ a subject seemingly irrelevant to the people of contemporary Paris.

The situation was ripe for some novelties. In the chaotic theatrical environment of Paris in the mid-19th century there gradually and fitfully emerged a form that represented the protest against serious opera. ${ }^{8}$ It was

4 Charles Rosen, The Classical Style (London: Faber, 1971), 164-83, in a detailed and perceptive but selective stylistic analysis, considers these two operas as a fusion of $s e$ ria and buffa.

5 Mozart's Die Zauberflöte is much more complex than is suggested by the features mentioned, because it operates as a pantomime, a pair of interconnecting romantic or quasi-romantic love stories and a masonic manifesto, sometimes simultaneously.

6 Hugh Macdonald, Berlioz (London: Dent, 1982), 34-6, spells out some of the main points, while David Cairns does so in much greater detail in the second volume of his majestic biography Berlioz: Servitude and Greatness 1832-1869 (London: Allen Lane, Penguin Press, 1999) in chapter 7, 157-75, ironically entitled 'Malvenuto Cellini'.

7 Cairns, Berlioz, chapter 24, 591-627, explains the difficulties met by the composer in his last years to achieve a satisfactory performance of his great epic opera, Les Troyens.

8 James Harding, Folies de Paris: the Rise and Fall of French Operetta (London: Chappell, 1979), 11-36, especially 22-3, vividly describes the haphazard and chaotic way that the situation evolved. 
light-hearted, relatively short and uncomplicated, and was often concerned with up-to-date domestic situations, while historical subjects or those from classic literature were often treated in a humorous or satirical fashion. Don Quichotte et Sancho Panza of 1848 by Hervé is sometimes considered the first operetta, though the word was not used until later. This form of theatrical musical entertainment became a distinct art-form under various names and was then developed extensively by Jacques Offenbach. Sometimes he took a humoristically ironic tone in his opéras bouffes, especially Orphée aux enfers (Orpheus in the Underworld), a scarcely disguised satire on the classical myth of Orfeo and La belle Hélène, a frivolous retelling of the Trojan myth. These theatrical works by Offenbach and many other composers whose names are all but forgotten became grouped under the umbrella heading 'operetta'.

In the later 19th century, operetta then spread across Europe from Paris to England with the operettas of Gilbert and Sullivan, euphemistically given the dignity of the title 'Savoy operas". Operetta also spread to Austria and neighbouring lands with works by so many composers that it is difficult to list them. Johann Strauss II's Die Fledermaus represents the genre at its most famous. For years the performances dominated the repertories of theatres, interrupted only by the onset of World War I.

\section{The Operatic Scene in Slovenia until 1913}

This pattern was apparent in Slovenia in the period up to the beginning of the First World War with a huge number of operatic performances, mostly in Ljubljana. These consisted of a wide range of musical theatrical works varying from grand opera to comic opera and operetta. Just as in the time when Offenbach was dominating the operetta scene in Paris, the terminology for these works was very 'flexible', as anything less serious than a comic opera was included under the title of 'operetta'. In the period from 1868 to 1913 works are freely described as grand opera, romantic opera, tragic opera, lyric opera, comic opera, operetta, comic operetta, melodrama, pantomime, spevoigre (melodrama or vaudeville) and numerous other titles. It is impossible because of the ambiguity of these terms to compile an accurate inventory of the types of works listed in the statistics included in

9 Bruno Bower, "London and Gilbert and Sullivan," in The Cambridge Companion to Operetta, ed. Anastasia Belina and Derek B. Scott (Cambridge: Cambridge University Press, 2020), 47-60, gives a concise and up-to-date presentation of the Gilbert and Sullivan collaborations. 
Repertoar slovenskih gledališč ('The Repertory of the Slovene Theatre') for these years ${ }^{10}$. For example, Benjamin Ipavec's Tičnik is called 'kratkočasna spevoigra' (entertaining melodrama) for an 1869 production, but merely 'opereta' for 1872 and $1888 .{ }^{\text {II }}$ For our purposes, however, it is helpful to give some idea of the scale of the activity in the Ljubljana Opera House in the period before the First World War. For the years 1868-1913, there are some 70 productions that could plausibly be included under the umbrella term 'operetta' (operetta, comic operetta, melodrama, pantomime, spevoigre) and with further performances the grand total of operetta performances in Ljubljana is approximately 350 . $^{\mathrm{I2}}$ The trend of operatic types is very interesting: in the early years from 1868 to 1895 operetta is featured considerably more frequently than more serious operas. After a period of steady decline in numbers, however, by 1896 the reduced frequency of operettas coincided with a corresponding increase in grand and romantic operas by composers such as Weber, Gounod, Meyerbeer, Bellini, Smetana, Wagner, Verdi and Leoncavallo. The operettas that were performed were represented by composers from Central Europe, like Johann Strauss II and Franz Suppé, as well as Offenbach and others, including some by the Slovene Viktor Parma and by the Croats Ivan Zajc and Srečko Albini. Interestingly, however, just before the First World War there was a considerable increase in the number of operetta performances. ${ }^{13}$ Productions of operettas by Emmerich Kálmán (Kálmán Imre) and Franz Lehár had numerous outings as did the classics by Offenbach and Strauss. The exuberant atmosphere at the time as reflected in social histories must have been present in the musical expectations of the general public and a certain denial of the coming storm which everybody was expecting. Then, in 1913 with the nine performances of the 'burlesque-operetta' Orpheus v podzemlju (Orpheus in the Underworld) by Offenbach and productions of Puccini's Madama Butterfly, Rossini's Seviljski brivec (The Barber of Seville) and Puccini's Tosca, there were no more professional operatic performances in Ljubljana until $1918 .^{14}$

Dušan Moravec, ed., Repertoar slovenskih gledališč 1867-1967 (Ljubljana: Slovenski gledališki muzej, 1967).

Ibid., 174, 175, 179.

Ibid., 173-204.

Ibid., 196-204.

Ibid., 203-4. 


\section{Slovene Operetta between the Wars - 1918-1945}

In Slovenia there was no delay re-establishing the activities of the opera house in Ljubljana and it was achieved with a popular operetta. It was on 21 November 1918, just ten days after the signing of the armistice, that the first of twelve performances of André Messager's frivolous operetta involving confused identities, Les P'tites michu of 1897 , launched the new era, on a wave of hope and optimism. It was followed by 41 performances of Smetana's ever popular comic opera Prodana nevesta ('The Bartered Bride'), together with operettas by Robert Planquette (Cornevillski zvonovi - 14 performances), the French composer Hervé (Mam'zelle Nitouche - 16 performances), Rudolph Piskaček (Slovaška princeska - 14 performances) and, inevitably, Offenbach (Madama Favart - 7 performances), to say nothing of more serious operas by Tchaikovsky (Jevgenij Onjegin/Evgenij Onegin 14 performances), Massenet (Manon - 17 performances) and Puccini (La Bohéme - 20 performances). ${ }^{15}$ The audiences in Ljubljana were now becoming more selective in the choice of operatic ventures, with a notable reduction in the number of performances of operettas and a corresponding increase in the number of performances of operas of all types.

There was another profoundly significant musical event soon after World War I. The opening of the opera house in Maribor in 1919 with the first of 15 performances on 1 May 1920 of Hervé's operetta Mam'zelle Nitouche gave Slovenes outside Ljubljana the opportunity of experiencing professional musical theatre. ${ }^{16}$ The establishment of this activity was on very firm footing as events proved, because during the time between the World Wars (1920-1941), the Maribor Opera House mounted the staggering number of 88 operettas with a total of some 300 performances. ${ }^{17}$ To add to this large number there were also eleven 'comic operas' and, probably as a temptation to audiences to explore beyond the frivolous nature of many of the operettas, some 30 'serious' operas (sometimes given other titles like romantic opera, dramatic romance and fairy tale opera). It was only after the presentation of 23 operettas and less well-known operas over two and a half years after the opening that Maribor witnessed professional performances of recognised classic full-scale operas with Gounod's Faust and Verdi's La Traviata, in December 1922 and January 1923 respectively. ${ }^{18}$

\footnotetext{
15 Ibid., 204-5.

16 Ibid., 431.

17 Ibid., 431-45.

18 Ibid., 431-33.
} 
Jože Sivec made the inter-war situation in Maribor situation very clear when he wrote:

Because of growing financial difficulties, however, in the 1928-29 season, musical performances had to be limited to operettas. In the seasons later on the annual repertoires again contained operas, even if not very many. ${ }^{19}$

The flood of new operettas must have been an incredible phenomenon that suited the spirit of the time and proved very helpful for the finances of the opera house. Many of these theatrical works were brought in from outside Slovenia, usually in translation, but there was a substantial number, however, from local composers, too. There are operettas by Viktor Parma (Caričine amazonke, Nečak), Radovan Gobec (Habakuk) and even Kozina (Majda), as well as ones by the Croatians Ivan Zajc and Srečko Albini, the Hungarian Emmerich (Imre) Kálmán as well as the constant stream of works from Austria. One can see that underlying these performances, there was in effect a long-running campaign to educate the audiences in the style and features of operatic performance. It was obviously a gradual process, because the more 'serious' operas were thinly scattered among the legions of operettas that made up the bulk of the musical productions, at least in the beginning.

\section{Radovan Gobec}

It was in this lively musical environment that the young and very talented Radovan Gobec (1909-1995) was working during the years 1924 to 1928 as a trainee teacher in Maribor. ${ }^{20} \mathrm{He}$ was soon to begin to compose his first operettas. These involved country settings, national folk tales, folk dancing, spoken dialogue and a sense of innocent living, together with music that was memorable melodically and rhythmically simple and repetitive. Emphatically it was all about the present, focussing on everyday lives, rather than the mythical and traditional subjects of classical opera.

Gobec's personal background is very illuminating. As related by Ivan Sivec, throughout his life he moved to different parts of Slovenia, gathering various cultural influences as he went. Certainly in his earlier years he

19 Jože Sivec, Dvesto let Slovenske opere - Two Hundred Years of the Slovene Opera (1780-1980) (Ljubljana: Opera in Balet SNG Ljubljana, 1981), 28, 84.

20 Ivan Sivec, Radovan Gobec: Mati Slovenije, tvoji smo sinovi ... (Maribor: Založba Obzorja, 2019), 11-8. 
absorbed many features of the countryside and its social environment. $\mathrm{He}$ was born in Podgrad near Ilirska Bistrica in the south of the country, where even at this young age he was in a strong musical environment in which his mother was an experienced choral singer. In 1912, just before the beginning of World War I, the family moved north to Celje. He attended primary schools, in Celje and in Šmihelj nad Pliberkom [St Michael ob Bleiburg - now part of Austria] and from 1919 to 1922 at the lower gymnasium in Celje. Because of his extraordinary musical talent, he also attended the Celje Music School from 1922 to 1924. In 1924, he enrolled as a trainee teacher in Maribor, where he studied until 1928. His most important teachers here were Hinko Druzovič (1873-1959) and Emerik Beran (1868-1940), who certainly must have been a strong influence. Happily for his future development, he studied both piano and violin. In the next ten years, he was active as a teacher, choral conductor and operetta composer.

It was this background which informed his interest in operetta. His first operetta Beg iz harema ('Escape from the Harem'), unfortunately now lost, was followed in 1930 by Hmeljska princesa (The Hop-Picking Princess) whose action is located in the area, the Savinja Valley, in which he was then working as a teacher at Griže by Žalec. It was first performed to great acclaim in 1933 in Žalec with local amateurs and running for some 20 performances, both in Žalec and Maribor. Sivec names as performers the Risto Savin mixed choir from Žalec, the Celje String Orchestra, various instrumental soloists, the dancers of the Bolero Dance School from Žalec and others.

\section{Planinska roža}

In a very colourful presentation of the background to Gobec's next operetta Planinska roža (The Highland Rose or The Mountain Flower) composed in 1937, Ivan Sivec notes that the environment for the operetta is the countryside to the south of Celje, notably below the Lisca mountain, near a village then called Henin (now Polana) fairly close to Juklošter, writing:

Mountains. The beauty of silence, peace, mountain flowers and birds singing. The chant of the soul, the self-confidence of Slovenian generations, the overcoming of oneself. All Slovenes, whether they admit it or not, are hikers at heart. Some are active, others just in their dreams. But definitely - like the sea - they carry mountains in their hearts, their souls. Especially during the young years, at the 
time of human maturity, at a time when a person wants to climb as high as possible. That's how it was with the young Radovan Gobec. At a time when he had already reached his first peak as a man and a creator, at the time when he felt the first strength in himself, at the same time, his life was regulated by his own taste, with all the abundance of work [...] he created one of the works that made him immortal because of his Sloveneness. ${ }^{21}$

The text of the operetta, written by Radovan Gobec himself, is concerned with the lives of the villagers, and is played without cloying sentiment, but with plenty of humour. It portrays idyllic life in the midst of the unspoiled nature of the Slovenian highlands. It is full of twists and turns, confused and confusing situations, but never becomes really serious. What is not part of the operetta is deep social satire, even if there are human frailties and petty jealousies. The plot centres around the figure of Katja as Sivec continues, quoting from a diploma thesis by Alenka Lavriša:

The lodger of the mountain hut Katja eats nicely and everyone wants to see her. It's mysterious. She chases hearts and hangs them on the wall. The local people know that she was already a film actress and a singer. Once upon a time, four members of the theatre go up and when they sing about Katja's song; the conductor Dobrovik has a thought and begins to write an operetta. At Gabernik's sighs, the text is drawn up. In the evening they go under Katja's window and sing: 'The mountain flower, you are love.'

The second act takes place at Gabernik's. His wife is jealous and asks for a new maid. At the same time they receive a message that Katja Silvan will be in the new operetta. When Katja appears, they call a maid who is being held to prevent them from causing a scandal. When a chorus of mountaineers and hikers come across the water, they find Katja - the much anticipated singer Katja Silvana - in the well. Following this is the finale [of act 3] that ends with the song of the Planinska roža. ${ }^{22}$

Musically the operetta is fluent and straightforward in its style and layout, with solos, solo ensembles, chorus parts and instrumental numbers to accompany the dances. The most obvious feature is the use of a 'motto theme', introduced at the beginning of the prelude. This consists of two

21 Ibid., 39.

22 Ibid., 41. 


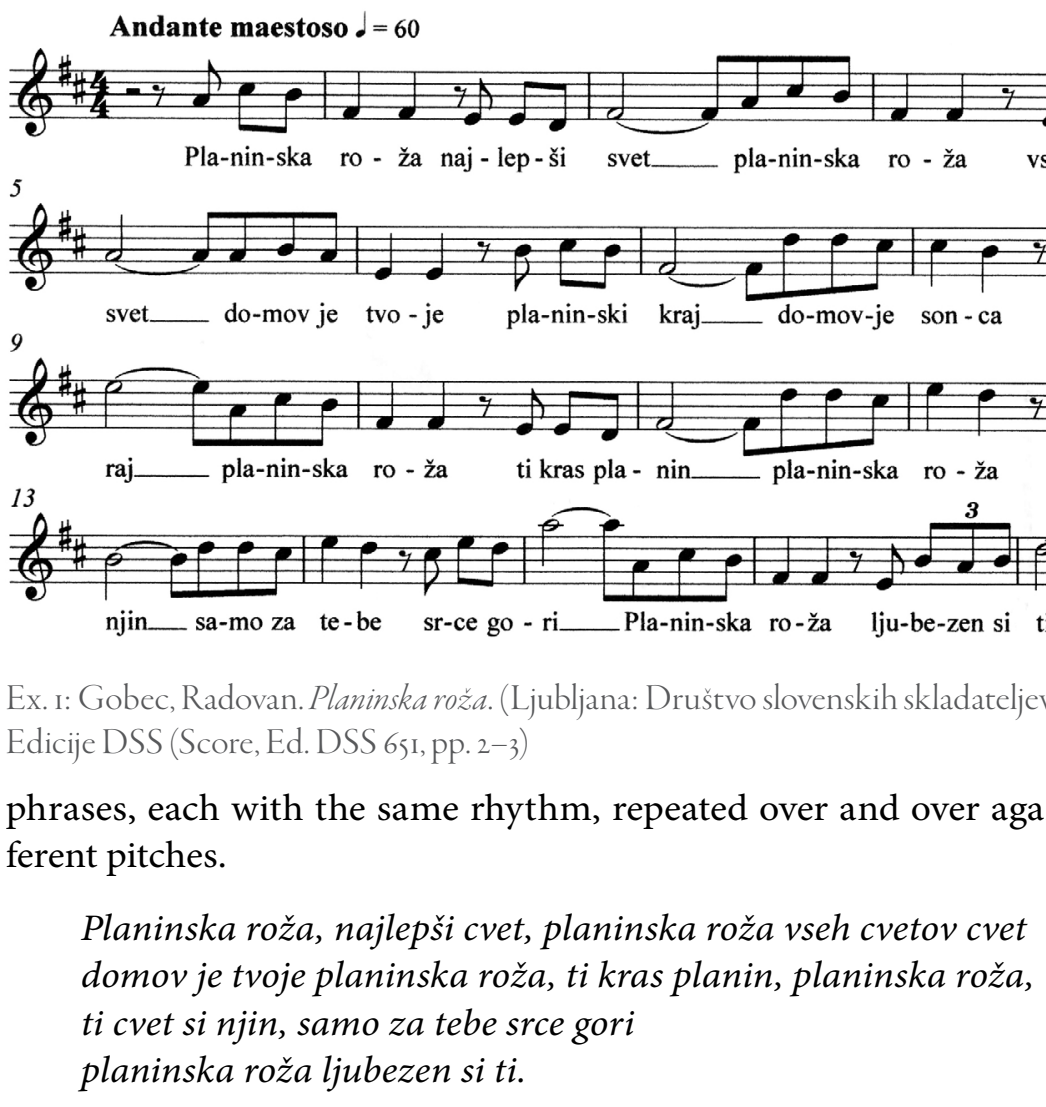

(Mountain flower, the most beautiful bloom, mountain flower of all flowers

the mountain flower is your home, you are a mountain of mountains,

mountain flower, you are a flower of theirs, my heart is burning only for you mountain flower my love is for you. $)^{23}$ [Ex. 1].

After a short introduction the motto song is presented by Katja and then by the chorus of villagers, while she, together with clarinets and cellos, decorates their music with florid phrases. This motto theme is immediately impressed on the audience, dominating the operetta in a manner that was to be common in musical theatre and in film music. It is in fact the most important feature to mark it out from Gobec's other operettas and in-

23 Radovan Gobec, Planinska roža, score (Ljubljana: Edicije DSS, 2019), 2-3. 
Adagio

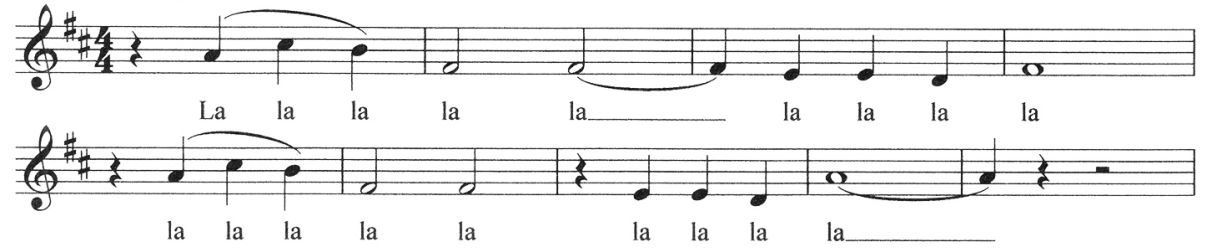

Ex. 2: Gobec, Radovan. Planinska roža. (Ljubljana: Društvo slovenskih skladateljev, 2019), Edicije DSS (Score, Ed. DSS 651, p. 19)

deed it is different from the general style of many operettas. It is then found in a group of three mini-variations that are character sketches for Dobrovik (Adagio 4/4 time) ${ }^{24}$ [Ex. 2].

Miran (Fox [trot] tempo, 2/2 time) $)^{25}$

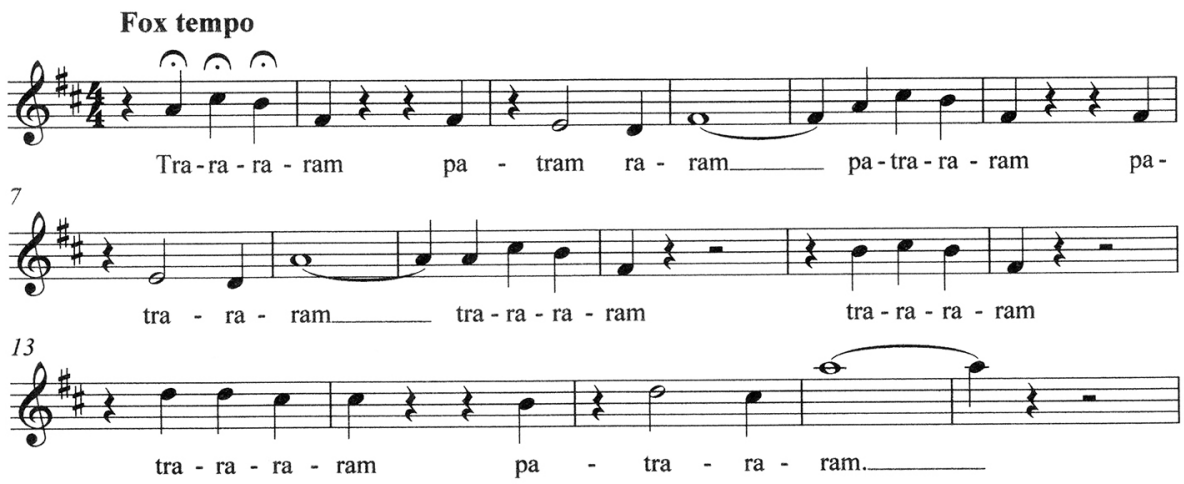

Ex. 3: Gobec, Radovan. Planinska roža. (Ljubljana: Društvo slovenskih skladateljev, 2019), Edicije DSS (Score, Ed. DSS 651, p. 20)

Miran and Dobrovik together with chorus adding a new and humorous dimension to the melody (Andante maestoso 4/4 time) ${ }^{26}$ [Ex. 4]. The melody thus takes on three different characters, with Gobec reinforcing the use of his tune by including it in the finales of each of the three acts. For other numbers in the musical setting he relied on simple forms and formulas. A series of five two-part songs with refrains is the standard form that Gobec then follows. Musical characterisation is fairly limited, probably because Gobec was relying on the progress of the complex drama being car-

\footnotetext{
24 Ibid., 19.

25 Ibid., 20.

26 Ibid., 21-2.
} 
Andante maestoso

Miran, Dobrivik

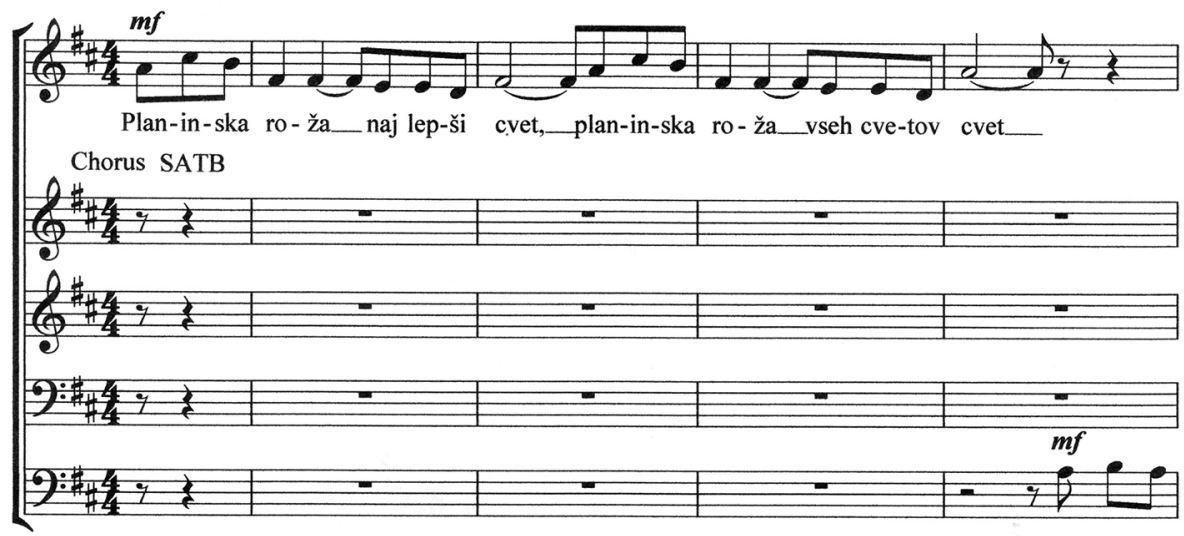

Do-mov-je

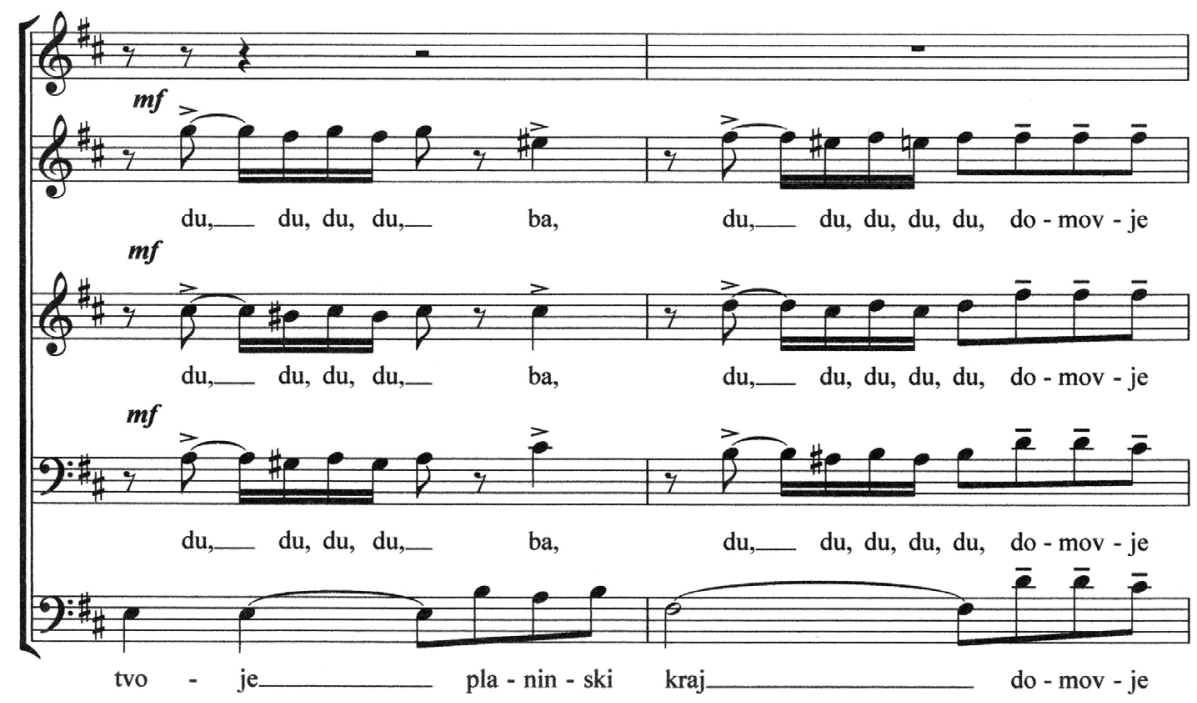




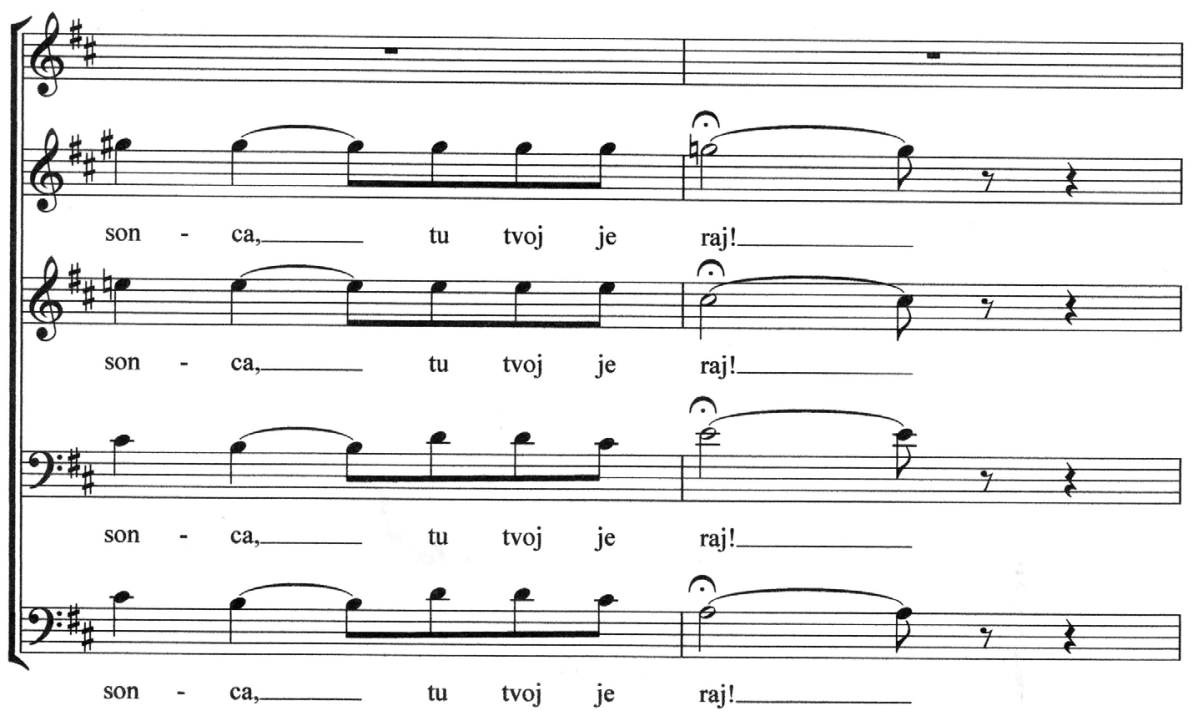

Ex. 4: Gobec, Radovan. Planinska roža. (Ljubljana: Društvo slovenskih skladateljev, 2019), Edicije DSS (Score, Ed. DSS 651, pp. 21-22, instrumental parts omitted).

ried on in the spoken actions, the large proportion of the plot being carried on in spoken dialogue. The songs effectively incorporate the solo singers and the chorus while ensuring the continuity of the plot.

Unlike many other operettas, there is only a limited number of dance sections, one in each of the three acts. In Act 1, the Balet Planinski cvet (Ballet of the Mountain Bloom) follows directly after the long instrumental coda of the previous Turistovska, a fast 3/4 waltz accompanying a solo tourist singing in praise of the hills in six simple eight-bar verses with a jolly eight-bar refrain from the chorus. The waltz moves in lively fashion with the chorus singing of dreams and sleep, while a contrasting section is slower (počasneje). In Act 2 a short section (Vivace 2/2) acts as prelude and ballet. In Act 3 the penultimate number (11a) is both duo for Kalan and Katja (koračnice - in march tempo 4/4) and a short dance acting as a prelude to the finale. The dance sections are clearly modest in their length and completely integrated into the musical and dramatic scheme.

Many of the work's features make it much closer to those of traditional opera. The use of the distinctive motto theme, extended both by repetition and by variation, moves in the direction of the later musical theatre works. The reduction in the length of the dance sections and their integra- 
tion into the dramatic structure enhances the plot towards a more tightly controlled plan.

Sivec notes the operetta's continued popularity as shown by performances in many places, not only in Slovenia:

Planinska roža has had many different performances (three times in Žalec, then in Cleveland, Murska Sobota, Majšperk, Postojna, Ljubljana, Maribor, Trieste and Osijek). ${ }^{27}$

He also makes important points about the nature of the operetta:

Gobec in Planinska roža discards dance diversity and strives for musical focus, which is achieved through the presentation of the central melody and even more by careful motivic work. This is probably not irrelevant for the libretto to offer besides standard operetta motives and moments of realism, but also the unusual crossing of the theatre stage, and the mixing of real and unreal events. It is the latter and also the replacement of dance-rhythmic sections with emphasized melodic shifts. Planinska roža is even slightly closer to opera, and such a shift towards a more serious genre is balanced by the stereotypical operatic typing of the main characters and the withdrawal into the mountain idyll. ${ }^{28}$

Gobec's last operetta Habakuk was composed in 1938 and first performed on Christmas Day 1940 in the National Opera House in Maribor and ran for 18 performances. ${ }^{29}$ Planinska roža, however, was not performed there until many years later. By now, however, the political situation was totally transformed, with the innocence of operetta being lost forever. Most of Europe was at war, but even so performances of operas and operettas took place in Ljubljana during the war years. Most of the productions featured well established operas, by such composers as Verdi, Donizetti, Puccini, Massenet, Mozart, Janáček, Beethoven and even Wagner. There were also operas by Slovenes and Croats: Matija Bravničar's Hlapec Jernej in njegova pravica, Danilo Švara's Kleopatra and Veronika deseniška, Kozina's Ekvinokcij were all performed in the war years or soon after, as was Ero the Joker by the Croatian Jakov Gotovac. Operettas were few and far between, consisting almost exclusively of the best known works of Strauss and Léhar. ${ }^{30}$

27 Sivec, Radovan Gobec, 44.

28 Ibid.

29 Moravec, Repertoar slovenskih gledališč 1867-1967, 445.

30 Ibid., 243-56. 
The dramatic change in the balance of opera and operetta had changed in Maribor, too. After the performances of Viktor Parma's Caričine amazonke in February 1941, there were no more productions at all until the performances in December 1945 of Smetana's Prodana nevesta (The Bartered Bride) and that is not considered an operetta as such. After World War II the Maribor opera house, like that in Ljubljana, abandoned operettas almost completely, with only the occasional productions of classics by Strauss and Léhar. ${ }^{31}$ This situation was summed up very clearly by Gregor Pompe:

Planinska roža was not only a success, but also there was a controversy about the significance of performing operettas, which was stirred up by the new government after the Second World War. Thus, a comparison of the schedules of the two Slovene opera houses from the time before and after the Second World War in terms of repertory, show, above all, that both institutions avoided performing operettas. ${ }^{32}$

\section{The Support for the Partisans}

In Slovenia, then part of Yugoslavia, during the war years there was the additional factor of the revolution taking place within its borders. Because support for Marshal Tito's Partisans was strong, a number of composers abandoned any work on 'serious' composition to join the forces of the Partisans with rousing militaristic songs. Not all composers were involved, but those that were, included Bojan Adamič, Ciril Cvetko, Marjan Kozina, Janez Kuhar, Karol Pahor, Rado Simoniti, Pavel Šivic, Franc Šturm, and Radovan Gobec. ${ }^{33}$ It was at this stage that Gobec abandoned operetta for his dedicated war effort with the Partisans ${ }^{34}$ and was now in the forefront of the

31 For the years 1945-50 see Moravec, Repertoar slovenskih gledališč 1867-1967, 445-50.

32 Gregor Pompe, "Operete Radovana Gobca," in Radovan Gobec (1909-1995), ed. Darja Koter (Ljubljana: Akademija za glasbo, 2010), 153.

33 Dragotin Cvetko, Slovenska glasba v Evropskem prostoru (Ljubljana: Slovenska matica, 1991), 386-87, 488, names some of the composers involved. Andrej Rijavec gives details of the wartime work of Rado Simoniti in Slovenska glasbena dela (Ljubljana: Državna založba Slovenije, 1979), 264-5. The context of Gobec's wartime situation is given by Veronika Šarec in "Množična, revolucionarna in delavska pesem na Slovenskem, vpeta v nacionalno gibanje 19. stoletja in družbeno-politične direktive 20. stoletja" in Radovan Gobec (1909-1995), 65-73.

34 Sivec, Radovan Gobec, 51-62, presents a comprehensive coverage of Gobec's World War II activities in vivid detail. 
performance of many of these patriotic songs. ${ }^{35}$ Prominent in his later postwar work in opera proper was Kri v plamenih of $1969 . .^{36}$ Ivan Sivec makes clear the important change in Gobec's life after the war:

To reinforce this change of direction Gobec now embarked on a fullscale musical training at Ljubljana's Academy of Music. Despite his successful career so far, he wanted to realize his intention to complete his musical education, so in 1946 he enrolled at the Ljubljana Central Music School, which in those days was still attached to the Academy of Music, and completed it in one year. In the following autumn, he then became a student of the Academy of Music, where he studied composition with Blaž Arnič and Lucijan Marija Škerjanc, and conducting with professor Danilo Švara. In both fields, he graduated with a concert in the Slovene Philharmonic in June 1951. Even before the war, as he says himself, he repeatedly wrote for advice to Emil Adamič and Slavko Osterc, who advised him on compositional issues. $^{37}$

\section{Slovene Operetta at the Crossroads}

The conclusion that we now reach is not about something that happened suddenly. It was a gradual process that transformed Slovene operetta. In the years before the First World War operetta was very strong while more serious opera was only modestly represented. There was, however, a short period in the early years of the 2oth century that saw a brief resurgence in the popularity of operetta as shown in the number of performances in Ljubljana. The Ljubljana opera house did not function during World War One, but started again immediately after the armistice in 1918. In 1919 the Maribor Opera House opened with a series of operettas and a small number of more serious operas. As in Ljubljana the nature of the productions changed gradually with fewer operettas appearing. The feeling is that the audienc-

35 Archive recordings of Partisan music, stirring choruses with military band accompaniment, have been published on three CDs. The first is Naša partizanska pesem (Ljubljana: RTV Slovenija 101526, 1998) in which fifteen out of twenty-four choruses are directed by Radovan Gobec; the other two CDs are Bella ciao (Maribor, Ljubljana: Obzorja, Helidon 6770929, 1998) and Hej brigade (Maribor, Ljubljana: Obzorja, Helidon 6770928, 1998), in which all 33 choruses from both discs were directed by Gobec, who was also responsible for much of the scoring and arrangements.

36 Borut Smrekar, “Operna dela Radovana Gobca," in Radovan Gobec (1909-1995), ed. Darja Koter (Ljubljana: Akademija za glasbo, 2010), 133-43. 
es had become more accustomed to hearing and seeing more difficult plots and not the light and sometimes superficial works that dominated the early years of the productions in Maribor. There were certainly serious political events during the inter-war years which must have affected the choice of operas and operettas in both Ljubljana and Maribor. It is hardly a surprise that Marij Kogoj's Črne maske (Black Masks) was produced on 7 May 1929 and two of Slavko Osterc's one-act operas on 27 February $1932 .{ }^{38}$ Even during World War Two there were regular productions in Ljubljana but not Maribor, although by 1945 the appetite of the audiences for operetta had clearly waned in both cities. The relatively few performances of operetta from around 1945 would have consisted of nostalgic productions that recalled the 'olden' days of innocence. The Slovene audiences had become more sophisticated in their preferences. One can with some justification mark out Radovan Gobec's Planinska roža as the work that set Slovene operetta and opera on a new course, one that is indicated by the emergence of such Slovene operas as those by Kozina, Bravničar and Pavel Šivic soon after the end of World War II. Gobec had faced the political and social realities of the war in his work with the Partisans. After the war he underwent a full musical training and almost totally abandoned operetta as a type, concentrating on opera as such, notably Kri v plamenih (Blood in Flames) of 1969 and several very impressive cantatas. In a sense he was now accepting the new situation in which operetta as he knew it was now inexorably being supplanted by Musical Theatre, or in its universally employed term, The Musical, especially in its emergence in English-speaking contexts in Europe and the United States. From then on in Slovenia, operetta survived in a modest way as an occasional light-hearted entertainment and a nostalgic reminder of the past.

\section{Acknowledgement}

The music examples are quoted by kind permission of Edicije DSS Ljubljana (www.dss.si).

\section{Bibliography}

Belina, Anastasia and Derek B. Scott, eds. The Cambridge Companion to Operetta. Cambridge: Cambridge University Press, 2020.

Bower, Bruno. "London and Gilbert and Sullivan." In The Cambridge Companion to Operetta, edited by Anastasia Belina and Derek B. Scott, 47-60. Cambridge: Cambridge University Press, 2020. 
Cairns, David. Berlioz: Servitude and Greatness 1832-1869. Vol. 2. London: Allen Lane, Penguin Press, 1999.

Cvetko, Dragotin. Slovenska glasba v Evropskem prostoru. Ljubljana: Slovenska matica, 1991.

Dent, Edward J. Mozart's Operas: A Critical Study. London: Oxford University Press, 1947.

Everett, William A. and Paul R. Laird, eds. The Cambridge Companion to the Musical. $3^{\text {rd }}$ ed. Cambridge: Cambridge University Press, 2017.

Gobec, Radovan. Planinska roža, score. Ljubljana: Edicije DSS, 2019.

Harding, James. Folies de Paris: the Rise and Fall of French Operetta. London: Chappell, 1979.

Koter, Darja, ed. Radovan Gobec (1909-1995). Ljubljana: Akademija za glasbo, 2010.

Lamb, Andrew. "Operetta." In The New Grove Dictionary of Opera. Vol. 3. Edited by Stanley Sadie, 707-13. London: Macmillan, 1992.

Lamb, Andrew. 150 Years of Popular Musical Theatre. New Haven: Yale University Press, 2000.

Lavriša, Alenka. "Radovan Gobec in njegovo delo.” Master's thesis, University of Ljubljana, 1999.

Macdonald, Hugh. Berlioz. London: Dent, 1982.

Moravec, Dušan, ed. Repertoar slovenskih gledališč 1867-1967. Ljubljana: Slovenski gledališki muzej, 1967.

Pompe, Gregor. “Operete Radovana Gobca.” In Radovan Gobec (1909-1995), edited by Darja Koter, 145-55. Ljubljana: Akademija za glasbo, 2010.

Rijavec, Andrej. Slovenska glasbena dela. Ljubljana: Državna založba Slovenije, 1979.

Rosen, Charles. The Classical Style. London: Faber, 1971.

Šarec, Veronika. in "Množična, revolucionarna in delavska pesem na Slovenskem, vpeta v nacionalno gibanje 19. stoletja in družbeno-politične direktive 2o. stoletja." In Radovan Gobec (1909-1995), edited by Darja Koter, 6573. Ljubljana: Akademija za glasbo, 2010.

Sivec, Ivan. Radovan Gobec: Mati Slovenije, tvoji smo sinovi ... Maribor: Založba Obzorja, 2019.

Sivec, Jože. Dvesto let Slovenske opere - Two Hundred Years of the Slovene Opera (1780-1980). Ljubljana: Opera in Balet SNG Ljubljana, 1981. 
Smrekar, Borut. "Operna dela Radovana Gobca." In Radovan Gobec (19091995), edited by Darja Koter, 133-43. Ljubljana: Akademija za glasbo, 2010.

Traubner, Richard. Operetta: A Theatrical History. New York: Doubleday, 1983. Reprint, Oxford: Oxford University Press, 1989.

Whenham, John. Claudio Monteverdi Orfeo. Cambridge: Cambridge University Press, 1986. 